\title{
Is Willingness to Communicate a Reliable Predictor of Learner Autonomy in an EFL Context?
}

Mohammad Mohammadi ${ }^{1}$ And Ziba Mahdivand ${ }^{\star 2}$

$\approx$ The present quantitative study investigated the relationship between willingness to communicate (WTC) and learner autonomy in an EFL context. In addition, it explored the probable effect of gender on the relationship between learner autonomy and WTC. Furthermore, it investigated whether WTC could predict learner autonomy. The data were collected from 142 upper-intermediate and advanced EFL learners ( 72 males and 70 females) by means of two questionnaires, the Learner Autonomy Questionnaire and the WTC Scale. The findings indicated that WTC correlated significantly and positively with learner autonomy. Moreover, correlational analysis revealed that gender modified this relationship in that the relationship between WTC and learner autonomy was stronger and more positive among female learners. The results revealed that WTC was a partial predictor of learner autonomy in this EFL context.

Keywords: communication, EFL learners, learner autonomy, willingness to communicate 


\section{Ali je pripravljenost za sporazumevanje zanesljiv napovednik učenčeve avtonomije v kontekstu učenja angleščine kot tujega jezika?}

Mohammad Mohammadi in Ziba Mahdivand

$\propto$ Kvantitativna študija je preučevala razmerje med pripravljenostjo za sporazumevanje (ang. WTC) in avtonomijo učenca v kontekstu učenja angleščine kot tujega jezika. Preučevala je tudi mogoč vpliv spola na odnos med avtonomijo učenca in pripravljenost za sporazumevanje. Poleg tega je preučila, ali bi na osnovi pripravljenosti za sporazumevanje lahko predvideli stopnjo avtonomnosti učencev. $\mathrm{V}$ raziskavi je sodelovalo 142 učencev, ki so bili na srednji oziroma višji ravni znanja angleščine (72 anketirancev moškega in 70 ženskega spola). Izpolnili so dva anketna vprašalnika, in sicer vprašalnik o avtonomiji učencev in lestvico o pripravljenost za sporazumevanje. Izsledki so pokazali statistično pomembno pozitivno povezanost med pripravljenostjo za sporazumevanje in avtonomijo učencev. Poleg tega je korelacijska analiza pokazala, da je glede na spol povezanost med pripravljenostjo za sporazumevanje in avtonomijo učencev višja in bolj pozitivna pri učenkah kot učencih. Pomembna ugotovitev je tudi, da je pripravljenost za sporazumevanje delni napovednik avtonomije učencev v kontekstu učenja angleščine kot tujega jezika.

Ključne besede: sporazumevanje, učenci angleščine kot tujega jezika, učenčeva avtonomija, pripravljenost za sporazumevanje 


\section{Introduction}

Throughout language learning experiences, there are a plethora of situations in which learners are not provided with ample opportunities to use the target language communicatively. Most often, learners have the required language knowledge but lack communicative skills to express themselves. As Little (2007) indicates, students are not just language learners but also active users of the language for communicative purposes. Furthermore, more often than not, language learners are not capable of using language independently in foreign language (L2) environments. The majority of EFL classes in Iran including secondary schools, universities, and language institutes are conducted in a lockstep style in which very few opportunities are provided for language learners to use English independently of the help of their teachers. In addition, rarely are language learners provided with the chance to use their own understanding and knowledge of the language communicatively in and outside of the classroom. Learners' need for interaction and transmission of their ideas and purposes has highlighted the undeniable role of using language to communicate in second and foreign language teaching and learning in recent decades.

To augment the above-mentioned issue, MacIntyre, Clément, Dörnyei, and Noels (1998, p. 547) further stated that, 'language learning should engender the learners' willingness to seek out communication opportunities and their willingness actually to communicating in them. Thus, as far as willingness to communicate is concerned, the concept of motivation and freedom that seem necessary and effective to initiate communication should be taken into consideration. Hence, McCroskey (1992) maintains that willingness is a phenomenal aspect that an individual opts for setting off communication when $\mathrm{s} / \mathrm{he}$ feels free to do so. In pursuing what MacIntyre et al. (1998) hold, willingness to communicate refers to getting involved in a discourse at a specific setting, including time and person, when one intends to use the $\mathrm{L} 2$ as a means of communication.

Therefore, it seems that motivation and autonomy are two essential requisites to initiate WTC. To support this argument, Deci (1971) suggests that autonomy is a significant factor in assisting any individual to resolve the problems he/she faces in daily life. The need for emphasis on WTC and making learners autonomous in learning has long been acknowledged. In fact, one should bear

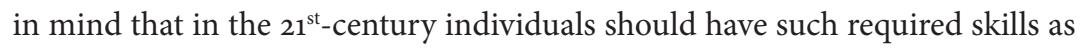
problem-solving, autonomous learning, and enthusiasm to communicate willingly and autonomously. Therefore, to help learners become autonomous and communicate appropriately in different language settings, these issues should be probed meticulously. 
To develop more mindful and responsible learners, learner autonomy appears to be a requisite factor in improving learners' capabilities in recognising and analysing their real-life needs. Furthermore, acquiring such abilities can assist learners in obtaining the essential confidence to initiate and become involved in communicative situations more willingly. As Kumaravadivelu (2006) suggested, learner autonomy and WTC are highlighted in post-method pedagogy in a way that the instructors may examine those concepts and transfer them to the learners. Furthermore, the key components of WTC including context and receiver types have been an under-investigated area in the literature in regard to the roles they can serve in predicting learner autonomy. The present study is an attempt to determine the possible correlations between gender and its effects on WTC and learner autonomy.

\section{Willingness to communicate (WTC)}

The notion of willingness to communicate (WTC) was first put forward by McCroskey (1992) to illuminate the different personalities individuals demonstrate in their communication in their first language. He points out that among different aspects of behaviour, shyness might cause inefficient communication. If it is detected in a sound way, it might lead to WTC from unwillingness to communicate. Hence, WTC is supposed to pave the way for an efficient order of thinking and ultimately for higher language proficiency and sound communication. According to Brown (2007), WTC has been interpreted as a cornerstone displaying the tendency toward or away from communicating and has been considered pertinent to the issue of shyness as most learners are unwilling to communicate in L2.

Most researchers have attempted to research the concept of WTC from different perspectives. Primarily, McCroskey and Richmond (1991) conceptualised WTC as a 'personality trait reflecting a stable predisposition to initiate communication in different situations' (p. 95). From this, it can be understood that WTC is a process (whose elements include context, receiver, and fillers) the should be encouraged among learners in order to use L2 in different settings. However, contrary to what McCroskey and Richmond (1991) claimed, MacIntyre et al. (1998) argued that WTC comprised both trait (stable) and state (transient) properties. Thus, according to MacIntyre et al. (1998), various situations are conceivable in which WTC might be affected. This would accordingly have consequences for learners. MacIntyre et al. (1998) further claimed that L2 teachers should make WTC a priority in their classes and that learning context should induce learners' willingness to look for opportunities for communication and their willingness to become involved in it. Skehan (1989) believed that 
utilising WTC not only predicts L2 use but also facilitates its development. Skehan defined WTC as 'willingness to talk in order to learn' (p. 48).

In MacIntyre's (1994) model, WTC appeared to be meaningfully and significantly influenced and predicted by the two concepts of perceived competence and communication anxiety. Later, MacIntyre and Charos (1996) revised MacIntyre's (1994) model of WTC, utilising Gardner's (1985) socio-educational model to examine the relation among personality characteristics, such as selfesteem, language anxiety, motivation, and perceived competence and social constructs, such as attitudes, motivation, WTC, and authentic language use, through a model called the 'Path Model'. The outcome was that learners with high motivation and perceived communication competence displayed greater WTC. Moreover, it was found that anxiety had an indirect effect on WTC through perceived communication competence and motivation whereas context directly influences the frequency of L2 communication. Furthermore, a number of studies revealed direct and indirect effects of motivation in relation to WTC (Baker \& MacIntyre, 2003; Hashimoto, 2002; MacIntyre, Baker, Clement, \& Conrod, 2001; Yashima, 2002).

Kang (2005) explained WTC as 'an individual's volitional inclination towards actively engaging in the act of communication in a specific situation, which can vary according to interlocutor(s); learners with higher WTC are of higher L2 achievement and have a greater inclination to communicate in real classroom contexts'.

In a study carried out in an Iranian context, Alemi, Tajeddin, and Mesbah (2013) investigated the effect of Iranian EFL individual differences on their L2 WTC and, based on the results, this effect was partially confirmed. The study was conducted among three groups of junior high school, senior high school, and university students. The results revealed that female students were more willing to communicate than males were, particularly in the junior high school group. Furthermore, they found no significant difference among the participants in terms of academic major, age, and personality types.

In another study on Iranian students' WTC, Hamzehnejad and Shariati (2014) examined the difference in the degree of willingness to communicate among azad (or private) and state (the non-state universities are supervised by the ministry of Higher Education) universities. The data were gathered via a questionnaire on WTC, exploring twelve contexts in which the students would choose to communicate. The result of the study showed no difference in the degree of WTC between two groups of students.

Aliakbari, Kamangar, and Khany (2016), in their study on the willingness to communicate in English among Iranian EFL students, concluded that 
learners' willingness to communicate is directly related to their attitude toward the international community, their perceived linguistic competence and selfconfidence. In other words, learners' view of linguistic competence and their feeling of autonomy and confidence influence the degree of willingness to communicate that they show in learning contexts.

\section{Learner Autonomy}

According to Little (1995), autonomy can be explained as a capacity for critical reflection, decision making and independent action. He regarded autonomy as 'interdependence rather than independence' (p. 5). Indeed, no particular mode of practice was implied by learner autonomy and it does not appear to be an isolated concept. Instead, learner autonomy is dependent upon the quality of the pedagogical dialogue between teacher and learner. Some scholars claimed that autonomy is a buzzword that can be considered an educational goal that can be appropriately pursued in different contexts and not a specific method to be used in classes (Little, 1999; Littlewood, 1996; Nematipour, 2012). Considering learning a 'lifelong process', Jacob and Farrell (2001) stated that, as a concept, learner autonomy highlighted the role learners played in the learning context, and not the role teachers played, by encouraging learners to improve their learning. They noted that learner autonomy concentrates on process rather than product.

Cotterall (1995) defines learner autonomy as the extent to which learners display their capabilities to employ some strategies to feel responsible for their learning and notes that the difference in the level of autonomy among learners is, to some extent, due to the beliefs they hold about language learning. According to Higgs (1988), autonomy is 'a process in which the learner works on a learning task or activity and is largely independent of the teacher who acts as a manager of learning programme as a resource person' (p. 41). Additionally, Benson (2001) holds that learner autonomy is the capacity of the learners to take charge of or feel responsibility for their own learning in different forms and in various contexts. Recently, researchers investigated learner autonomy with regard to diverse factors including critical thinking abilities, learning styles, learners' perceptions in autonomy, and motivation (Ahmadi, 2013; Fahim \& Behdani, 2011; Nematipour, 2012; Peng \& Woodrow, 2010).

Ahmadi (2013) examined Iranian ESP learners' perceptions of autonomy in language learning. She investigated whether law students attending English for specific purposes were ready to be involved in autonomous language learning. Analysis of the results revealed that ESP students were not ready for autonomy, and they left most of the important decisions of their learning to their teachers. Mohammadpour (2013) conducted a study in which she investigated 
the relationship between autonomy and proficiency in the Iranian context. The results showed that English proficiency and learner autonomy had a significant relationship. That is, the students with similar autonomy had similar proficiency scores while students with different autonomy levels had different proficiency levels.

Considering the aforementioned issues and studies, the present study sets out to a) determine the probable relationship between WTC and learner autonomy in EFL contexts, b) identify the influences of gender on the abovementioned relationship, and c) discover the predictive power of willingness to communicate in terms of learner autonomy.

\section{Method}

\section{Participants}

The participants of the present study were selected from a language institute via convenience sampling. In such a method of sampling, the researcher selects participants who happen to be available for the study (Mackey \& Gass, 2005). Convenience sampling was used in this study since it was not practical to run a homogeneity test among the learners due to the regulations of the institute where the participants studied. Thus, the researcher asked those participants who were learning English at advanced levels in that language institute in Urmia, Iran, to participate. Due to numerous practical and administrative issues, the researcher was not allowed to use a proficiency test for homogenising the sample. Therefore, an in-house achievement test was considered as the main criterion to identify the participants' initial differences and to ensure the comparability of the sample. As the results of the in-house achievement test suggested, nearly all of the respondents were upper-intermediate and advanced language learners in the language institute. They came from various linguistic backgrounds and native languages including Turkish, Kurdish, and Persian. Out of 170 questionnaires distributed among participants, only 142 ( $83 \%$ response rate) were deemed appropriate for the analysis of the data since the rest were incomplete or replied without being attentive to the content of the present study. Out of 142 participants, 72 were males and 70 were females. Almost all learners were within the age range of $17-28$. The respondents were assured that the data would be kept confidential and would be used for research purposes only.

It is noteworthy to mention that, in Iranian settings, learners pay high amounts of tuition for attending language institute in order to remain current with ongoing international issues. In the Iranian context, students normally attend private language school after they pass their basic school courses (10-12 
years). A typical language institute includes about 15 intensive terms for children and adults separately that mainly aim to enhance learners' communicative capacities in line with global ELT developments. In the same vein, the language institutes do their best to assist their learners to accomplish their real-life learning objectives via employing up-to-date and interactive teaching techniques that are implemented by highly knowledgeable and skilful teachers. This is achieved through carefully-designed teacher training programmes that are mostly held at the beginning of the courses in order to update instructors' knowledge in regard to the current theoretical and practical teaching-related aspects.

\section{Instruments}

The participants' WTC level was measured using the willingness-to-communicate scale, developed by McCroskey and Richmond (1987). This instrument measures a learner's willingness to initiate communication and includes 20 items including eight referring to distract attention from the scored items (fillers) and 12 items covering four context-type scores (public, meeting, group, interpersonal) and three receiver-type scores (i.e., strangers, acquaintances, friends). While filling out the questionnaires, the participants were supposed to write appropriate percentages from o\% (never) to 100\% (always) according to their opinions. The initial version of the WTC questionnaire was administered to thirty EFL learners to assure the reliability of the scales. The Cronbach's alpha reliability coefficient for the scales of fillers, context-type, and receiver type were analysed to be .77, .79, and .82 , respectively. The reliability analyses for WTC questionnaire confirmed acceptable internal consistency for the three scales.

In addition, the questionnaire enjoyed a high level of face validity and the results of extensive research indicated the predictive validity of the instrument. Furthermore, the questionnaire underwent expert validation to ensure the appropriateness of the content. The researcher asked two experts in the field to go through the scales and report the existed inconsistencies, if any. It is worth mentioning that an additional factor analysis was run in order to analyse the total variance explained by each factor of the scale. It must be noted that the first component (context-type) accounted for $56.36 \%$ of the variance, the second (receiver-type) $42.33 \%$, and the third (fillers) $1.31 \%$.

The second data collection tool was the Learner Autonomy Questionnaire designed by Kashefian (2002). It includes 40 items in a five-point Likert scale, which are about the role of autonomy in L2 learning. Previous research (e.g., Dafei, 2007; Khabiri \& Heidari, 2011) demonstrated that this questionnaire enjoys high content validity and high reliability of $\mathbf{8 2}$. However, the researcher conducted a separate pilot analysis to ensure the context-specific 
reliability of the instrument. The results of the pilot study were congruent with the previous studies in reporting the high reliability levels. The reliability value of the learner autonomy questionnaire was analysed to be .80 using Cronbach's alpha reliability estimates.

\section{Procedure}

The WTC Scale and Learner Autonomy Questionnaire were distributed among 170 advanced level language learners in a language institute of Urmia in Iran. As the proficiency level of the participants was upper-intermediate and advanced, they had no trouble comprehending and completing the items of the questionnaires. As a result, there was no need to translate the items into their mother tongues. The questionnaires were distributed to learners in a period of two weeks and they were supposed to answer them in their break time in their classrooms. There was no time limitation for filling the questionnaires. As the questionnaires were not time-consuming, both were filled simultaneously. Participants handed them in after almost 20 minutes. Having collected the questionnaires, the researcher checked the appropriateness of the questionnaires; only 142 of the returned questionnaires were suitable for the purposes of the study. Therefore, the researcher decided to exclude the remaining 28 questionnaires due to incomplete answers. Correlational and regressions analyses were carried out using SPSS software (version 21) to analyse the data.

\section{Results}

\section{Learner Autonomy and WTC}

The relationship between learner autonomy and WTC was investigated using the Pearson-product-moment correlation coefficient. To ensure the normality and linearity of the data, preliminary analysis was performed. The outcome revealed a strong positive relationship between the two variables $(r=.83$, $\mathrm{n}=142, \mathrm{p}<.05$ ). In fact, a high level of learner autonomy correlated with a high level of willingness to communicate. This means that the higher the level of autonomy in learners, the higher the WTC they feel.

Table 1

Pearson Correlation for learner autonomy and willingness to communicate

\begin{tabular}{lll}
\hline$r$ & $\mathrm{~N}$ & $p$ \\
\hline 0.83 & 142 & .000 \\
\hline
\end{tabular}




\section{Gender, Learner Autonomy and WTC}

To answer the second question, which deals with the effect of gender on the relationship between learner autonomy and WTC, correlational analysis was carried out. As Table 2 shows, the levels of relationship among gender, learner autonomy and WTC appears to be different for male and female participants. In fact, this relationship is more significant and strong in the case of female participants $(\mathrm{r}=.81, \mathrm{n}=70, \mathrm{p}<.005)$ than in that of male learners $(\mathrm{r}=.73, \mathrm{n}=72$, $\mathrm{p}<.05)$. Thus, the relationship between learner autonomy and WTC is stronger among female learners.

Table 2

Gender effects in the relationship between WTC and leaner autonomy

\begin{tabular}{lccc}
\hline Gender & $\boldsymbol{r}$ & $\mathrm{N}$ & $\boldsymbol{p}$ \\
\hline Male & 0.73 & 72 & .000 \\
Female & 0.81 & 70 & .000 \\
\hline
\end{tabular}

\section{Predictive Power of WTC on learner autonomy}

A standard regression analysis was run to predict learner autonomy through learners' WTC. Learner autonomy was entered as the dependent variable and WTC as the independent variable. As shown in Table 3, willingness to communicate is the predictor entered into the regression model.

Table 3

Regression model summary of willingness to communicate and learner autonomy

\begin{tabular}{lrccccc}
\hline Model & $\begin{array}{r}\text { Sum of } \\
\text { Squares }\end{array}$ & df & $\boldsymbol{F}$ & $\mathrm{R}^{2}$ & Adjusted $\mathrm{R}^{2}$ & $\boldsymbol{P}$ \\
\hline Regression & 988.44 & 1 & 8.04 & 0.78 & .064 & .000 \\
Residual & 9591.81 & 141 & & & \\
Total & 11580.26 & 142 & & & \\
\hline
\end{tabular}

The R-square for WTC is .078, meaning that willingness to communicate can nearly predict 8 per cent of learner autonomy. The result of ANOVA indicated that WTC can partially predict learner autonomy $(\mathrm{F}=8.04, \mathrm{P}=<.05$, $\left.\omega^{2}=.07\right)$. 


\section{Discussion}

In the present study, a significant positive relationship was found between learners' autonomy and their WTC. The higher the degree of autonomy they perceived, the greater the WTC they felt. The findings of this study are in line with the results of previous studies (Cameron 2013; Kang, 2005; Khaki, 2013; Zarrinabadi \& Abdi, 2011). Partially similar to the present study, Khaki (2013) found a significant strong relationship between learner autonomy and trait-like WTC in Iranian EFL learners and a significant but weak correlation between learner autonomy and situational WTC in Iranian EFL learners. Based on these findings, it can be postulated that both WTC and learners' autonomy may serve a significant role in language learning and can lead to a successful learning experience.

The results of the present study also agree with two other studies. First, Egel (2009) noted that collaboration and interaction are key factors in developing learner autonomy in classroom context and class participation is mainly based on the learners' high levels of inclination toward communication acts, that is, trait-like WTC (Zarrinabadi \& Abdi, 2011). Second, Cameron (2013) recognised that both trait and situational factors have a great effect on students' WTC. She also concluded that factors such as self-perceived competence, personality, motivation, the importance of English and the learning context significantly influence learners' success.

However, the findings obtained from this study are in contradiction with what Scharle and Szabo (200o) stated. They claimed that the goal of autonomous learners is just to learn the subject and benefit from this so that they may not be eager for group work or even willing to communicate. Additionally, unlike Khaki (2013) who found no significant influence by gender on the relationship between learner autonomy and WTC, the results of this research are in the same vein with the findings of the study carried out by Deci and Ryan (2002).

This potential relationship between learner autonomy and WTC could be related to instructors, learners, and syllabus designers' tendency toward moving the learning environment from the traditional artificial atmosphere to a more real-life experience. Accordingly, Zarrinabadi and Abdi (2011) highlighted that both WTC and learner autonomy are prerequisites for being successful in the language learning arena which means that in order to be successful, an individual needs enhanced levels of learner autonomy and WTC. Similarly, Kang (2005) concluded that the potential relationship between WTC and learner autonomy may result in more active and autonomous learning on the part of the learners. 
Another explanation for the strong correlation between learner autonomy and WTC can be the fact that autonomy has frequently been considered in terms of its appropriateness in educational contexts and the related aspects such as learners' willingness to take part in communication processes. As Candy (1991) explains, learner autonomy is not a static product reached once and for all due to independence from teachers but is a perennial dynamic process amenable to educational interventions that help learners to assume more responsibility over their learning and become more willing to be involved in their learning process.

Moreover, many scholars highlighted the above-mentioned roles of autonomy in education and language learning and provided their interpretations of autonomy based on those facts. Besides, the findings of a plethora of studies substantiate the vital role of learner autonomy in language learning (Haghi, 2009; Little, 2007; Scharle \& Szabo, 2000), and the effects of WTC (Riasati \& Noordin, 2011; Yashima, 2002; Zarrinabadi \& Abdi, 2011) on language learners' success. For instance, Littlewood (1996) stated that one of the domains of autonomy is the concept of autonomy as a communicator, which implies an individual's communication in specific situations. In this regard, autonomy involves the concept of WTC and, more specifically, situational WTC.

The second objective of the study was to investigate the roles of gender in affecting the relationship between learner autonomy and willingness to communicate. In this regard, female learners revealed a strongly more positive relationship than their male counterparts had. In fact, the relationship between learner autonomy and WTC is stronger among female learners than male ones.

This finding is in line with the previous research conducted on learner autonomy (Crookall \& Ho, 1995; Najeeb, 2013; Tanyeli \& Kuter, 2013) and WTC (MacIntyre, Baker, Clement, \& Donovan, 2002; Donovan \& MacIntyre, 2004) that highlighted the influential role played by gender on the relationship between learner autonomy and WTC. Similar to this study, Smith (1997) confirmed that adolescent female learners showed more willingness to initiate communication than their male counterparts did. This outcome disagrees with Tannen (1990), who determined that men are more willing to communicate than females in classrooms and in discussions

Given the similar findings of the previous studies, the question remains as to why female learners are more enthusiastic about engagement in communicative learning experiences. It can be postulated that female learners appear to have developed high levels of motivation particularly intrinsic motivation. This, in turn, may be related to their individualistic characteristics that lead them to demonstrate more willingness to become involved in communicative 
events. Those individualistic characteristics can include self-confidence, selfefficacy, self-esteem, and risk-taking capabilities. For instance, female learners may feel more confident and are convinced to take risks while learning a foreign language. In fact, in Iranian settings, female learners are offered fewer opportunities to be involved in decision-making policies in comparison to their male counterparts. Hence, they endeavour to express themselves as soon as they find an appropriate site make their voices heard as members of society.

The result of regression analysis was an endorsement for the previous findings (Zarrinabadi \& Abdi, 2011) regarding the possibility that learners with higher levels of WTC can manifest more autonomy in different learning and communicative situations. The outcomes revealed that WTC could weakly predict the existence of learner autonomy in language learners in the context of EFL. This finding is in line with Khaki (2013), as he recognised a weak-tomoderate value of prediction. He indicated that a learner may have a high level of WTC, but when put in a situation in which that can use their newly acquired language, they may not show sufficient eagerness to communicate due to some situational variables.

Thus, being more willing to communicate in the target situation does not necessarily mean that learners have developed higher levels of autonomy. In fact, there may be other possible reasons that contribute to their great reluctance for communication only one of which can be autonomy, as indicated in this study. In the case of high WTC, for example, motivation, topic familiarity, and the context may have contributory effects. With respect to learner autonomy, there can be predictors other than willingness to communicate, including different language learning styles, such as field-independence. Therefore, any action that leads to the development of these two concepts should be taken into consideration

\section{Conclusion}

Learner autonomy can help language learners make sound decisions in language learning. It also assists learners in acting autonomously which, in turn, will make them feel responsible, interactive and cooperative. Hence, autonomy paves the way for language learners to not only succeed in language learning but also motivates them to generate new ideas to improve their overall language proficiency in L2. The significant positive relationship between learner autonomy and WTC in this study indicates that these two variables go hand in hand in Iranian EFL context. On the positive side, the positive role of gender in this relationship might suggest that males and females react differently 
regarding the feeling of autonomy and WTC in Iran. Female learners with high level of autonomy displayed more WTC in this study. However, this was not totally true in case of male participants as some male learners with a high level of learner autonomy demonstrated a low level of WTC. This indicated that the female participants with high levels of autonomy are more willing to communicate in Iranian language learning context whereas this is not so with the male participants. Not all the male participants with high levels of autonomy showed great degrees of WTC in their language learning performance. It is worth mentioning that the Iranian female population is almost entirely marginalised in the majority of social and economic aspects and mostly males adopt the most prestigious societal and occupational opportunities. This may be one reason for female learners' high levels of willingness to communicate via showing more autonomous behaviours.

Thus, it can be said that learners with high levels of WTC generally tend to be autonomous learners. However, this relationship was not shown to be significant in this study. In conclusion, regarding the importance of learner autonomy and willingness to communicate, the findings of this study should be considered by teachers, material developers, curriculum designers and policy makers in giving the learners more freedom and providing more inspiring contexts to make them more willing to communicate in learning. The major finding of the present study is that WTC does not predict learner autonomy significantly, which, in practical terms, means that teachers are recommended to improve their learners' WTC as one contributing factor if they aim to boost their autonomous language learning and use.

Like most studies, the present study was limited in a number of aspects. First, it was quantitative in design. It is suggested that qualitative research methods such as interviews and observations be utilised to gather more indepth data. Next, no proficiency test was administered to accurately assess the participants' proficiency level. More accurate results are likely to be obtained if future research is based on assessments gained from the administration of a proficiency test. It is noteworthy, however, that the participants' proficiency was not a major obstacle in the current study as it was not taken into account as a significant factor or as a focus of attention. Finally, studies with a greater number of participants are recommended for the purposes of the generalisability of the findings. 


\section{References}

Ahmadi, R. (2013). Iranian ESP learners' perceptions of autonomy in language learning. International Journal of Applied Linguistics \& English Literature, 2(1), 28-34.

Alemi, M., Tajeddin, Z., \& Mesbah, Z. (2013). Willingness to communicate in L2 English: Impact of learner variables. Journal of Research in Applied Linguistics, 4(1), 42-61.

Aliakbari, M., Kamangar, M., \& Khany, R. (2016). Willingness to communicate in English among Iranian EFL Students. English Language Teaching, 9(5), 33-45.

Baker, S. C., \& MacIntyre, P. D. (2003). The role of gender and immersion in communication and second language orientations. Language Learning, 53(1), 65-96.

Benson, P. (2001). Autonomy in language learning. Harlow, UK: Longman.

Brown, H. D. (2007). Principles of language learning and teaching (5th ed.). New York, NY: Pearson Education.

Cameron, D. (2013). Willingness to communicate in English as a second language as a stable trait or Context influenced variable: Case studies of Iranian migrants to New Zealand. Australian Review of Applied Linguistics, 36(2), 177-196.

Candy, P. (1991). Self-direction for lifelong learning. San Francisco, CA: Jossey-Bass.

Cohen, L., Manion, L., \& Morrison, K. (2007). Research methods in education (6th ed.). London, UK: Taylor \& Francis Group.

Cotterall, S. (1995). Readiness for autonomy: Investigating learner beliefs. System, 23(2), 195-205.

Crookall, D., \& Ho, J. (1995). Breaking with Chinese cultural traditions: Learner autonomy in English language teaching. System, 23(2), 235-243.

Dafei, D. (2007). An exploration of the relationship between learner autonomy and English proficiency. Asian EFL Journal, 24(1), 5-30.

Deci, E. L. (1971). Effects of externally mediated rewards on intrinsic motivation. Journal of Personality and Social Psychology, 18(1), 105-115.

Deci, E. D., \& Ryan, R. M. (2002). Handbook of self-determination research. New York, NY: University of Rochester Press.

Donovan, L. A., \& Maclntyre, P. D. (2004). Age and sex differences in willingness to communicate, communication apprehension, and self-perceived competence. Communication Research Reports, $21(4), 420-427$.

Egel, I. P. (2009). Learner autonomy in the language classroom: From teacher dependency to learner independency. Procedia Social and Behavioral Sciences, 1(1), 2023-2026.

Fahim, M., \& Behdani, R. SH. (2011). Critical thinking ability and autonomy of Iranian EFL learners. American Journal of Scientific Research, 29, 59-72.

Gardner, R. C. (1985). Social psychology and second language learning: The role of attitudes and motivation. London, UK: Edward Arnold.

Haghi, M. (2009). The relationship between perceived self-efficacy and Iranian EFL learners' autonomy (Unpublished master's thesis). Tehran: Islamic Azad University. 
Hamzehnejad, F., \& Shariati, M. (2014). The comparison of willingness to communicate and the preferred contexts between the MA students of Kerman Azad University and Kerman institute of higher education. International Journal of Language Learning and Applied Linguistics World, 6(2), 371-380.

Hashimoto, Y. (2002). Motivation and willingness to communicate as predictors of reported L2 use: The Japanese ESL context. Second Language Studies, 20(2), 29-70.

Higgs, J. (1988). Planning learning experiences to promote autonomous learning. In D. Boud (Ed.), Developing student autonomy in learning (pp. 40-58). London, UK: Kogan Page.

Jacobs, G. M., \& Farrell, T. S. (2001). Paradigm shift: Understanding and implementing change in second language education. The Electronic Journal for English as a Second Language, 5(1), 1-17. Jamaleddin, Z. (2014). A comparison between male and female in their willingness to communicate and use of socio-affective strategies. International Journal of Educational Investigations, 2(4), 70-81. Kang, S. J. (2005). Dynamic emergence of situational willingness to communicate in a second language. System, 33(2), 277-292.

Kashefian, S. N. (2002). An investigation into college EFL learners' beliefs demonstrating their predispositions towards learner autonomy (Unpublished master's thesis). Shiraz: Shiraz University. Khabiri, M., \& Heidari, M. (2011). The relationship among EFL learners' left/right brain dominance, autonomy, and reading comprehension of the academic and general reading modules of IELTS. Journal of Language and Translation, 2(1), 59-77.

Khaki, Sh. (2013). The relationship between learner autonomy and willingness to communicate (WTC) in Iranian EFL learners. International Journal of Applied Linguistics \& English Literature, 5(2), 97-109.

Little, D. (1995). Learning as dialogue: The dependence of learner autonomy on teacher autonomy. System, 23(2), 175-181.

Little, D. (1999). Developing learner autonomy in the foreign language classroom: A socialinteractive view of learning and three fundamental pedagogical principles. Revista Canaria de Estudios Ingleses, 38, 77-88.

Little, D. (2007). Language learner autonomy: Some fundamental considerations revisited. Innovation in Language Learning and Teaching, 1(1), 14-29

Littlewood, W. (1996). "Autonomy": An anatomy and a framework. System, 24(4), 427-435. Littlewood, W. (1999). Defining and developing autonomy in East Asian contexts. Applied Linguistics, 20(1), 71-94.

MacIntyre, P. D. (1994). Variables underlying willingness to communicate: A causal analysis.

Communication Research Reports, 11(2), 135-142.

MacIntyre, P. D., Baker, S. C., Clement, R., \& Conrod, S. (2001). Willingness to communicate, social support, and language-learning orientations of immersion students. Studies in Second Language Acquisition, 23(3), 369-388.

MacIntyre, P. D., Baker, S. C., Clement, R., \& Donovan, L. A. (2002). Sex and age effects on willingness to communicate, anxiety, perceived competence, and L2 motivation among junior high 
school French immersion students. Language Learning, 52(3), 537-564.

MacIntyre, P. D., \& Charos, C. (1996). Personality, attitudes, and affect as predictors of second language communication. Journal of Language and Social Psychology, 15(1), 3-26.

MacIntyre, P. D., Clément, R., Dörnyei, Z., \& Noels, K. A. (1998). Conceptualizing willingness to communicate in a L2: A situational model of L2 confidence and affiliation. The Modern Language Journal, 82(4), 545-562.

Mackey, A., \& Gass, S. M. (2005). Second language research: Methodology and design. New Jersey, NJ:

Lawrence Erlbaum Associates.

Mahmoodi, M. J., \& Moazam, I. (2014). Willingness to communicate (WTC) and L2 achievement:

The case of Arabic language learners. Procedia: Social and Behavioural Sciences, 98, 1069-1076.

McCroskey, J. C. (1992). Reliability and validity of the willingness to communicate scale.

Communication Quarterly, 40(1), 16-25.

McCroskey, J. C., \& Richmond, V. P. (1987). Willingness to communicate. In J. C. McCroskey \& J. A.

Daly (Eds.), Personality and interpersonal communication (pp. 129-156). Newbury Park, CA: SAGE

Publications.

McCroskey, J. C., \& Richmond, V. P. (1991). Willingness to Communicate: A cognitive view. In M.

Booth-Butterfield (Ed.), Communication, cognition, and anxiety (pp. 19-37). Newbury Park, CA:

Sage.

Mohammadpour, E. (2013). A three-level multilevel analysis of Singaporean eighth graders science achievement. Learning and Individual Differences, 26, 212-220. doi: 10.1016/j.lindif.2012.12.005

NajeebSabitha. S. R. (2013). Learner autonomy in language learning. Procedia- Social and Behavioural Sciences, 70, 1238-1242.

Nematipour, M. (2012). A study of Iranian EFL learners' autonomy level and its relationship with learning style. English Linguistics Research, 1(1), 126-136.

Peng, E. J., \& Woodrow, L. (2010). Willingness to communicate in English: A model in the Chinese EFL classroom. Language Learning, 6o(4), 834-876.

Riasati, M. J., \& Noordin, N. (2011). Antecedents of willingness to communicate: A review of literature. Studies in Literature and Language, 3(2), 74-80.

Scharle, A., \& Szabo, A. (200o). Learner autonomy: A guide to developing learner responsibility.

Cambridge, MA: Cambridge University Press.

Skehan, P. (1989). Individual differences in second language learning. London, UK: Edward Arnold. Smith, T. E. (1997). Adolescent gender differences in time alone and time devoted to conversation.

Adolescence, 32, 483-496.

Tannen, D. (1990). You just don't understand: Women and men in conversation. New York, NY:

Ballentine Books.

Tanyeli, N., \& Kuter, S. (2013). Examining learner autonomy in foreign language learning and instruction. Eğitim Araştirmalari-Eurasian Journal of Educational Research, 53, 19-36.

Yashima, T. (2002). Willingness to communicate in a second language: The Japanese EFL context. The Modern Language Journal, 86(1), 54-66. 
Zarrinabadi, N., \& Abdi, R. (2011). Willingness to communicate and language learning orientations in Iranian EFL context. International Educational Studies, 4(4), 206-214.

\section{Biographical note}

Mohammad Mohammadi, $\mathrm{PhD}$, is an assistant professor in TEFL from Urmia University, Iran. He is a specialist in phonetics and phonology and discourse analysis.

Ziba Mahdivand is an MA graduate in TEFL from Urmia University and has been teaching general and TOEFL iBT preparation courses for five years. She is interested in language teaching methodology to implement different ways of teaching to learners in order to see their effects. Her interest is also fostering general English skills in EFL classes. 